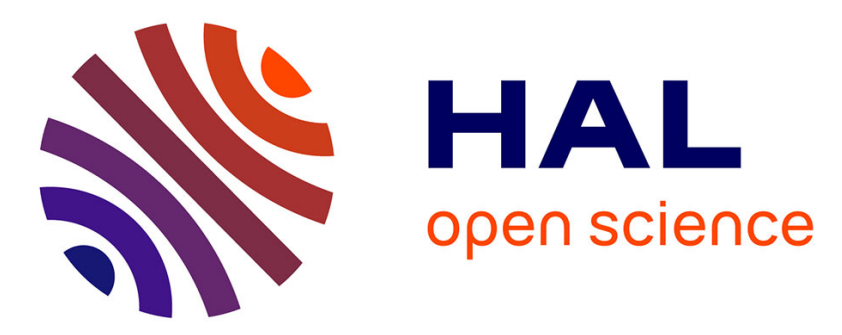

\title{
The Role of Oxidation Compounds in Biofilm Growth on Polyethylene Geomembrane Barriers Used in Landfill
}

C Pons, Emmanuel Richaud, T Bouchez, L Mazeas, F Farcas, B Fayolle

\section{To cite this version:}

C Pons, Emmanuel Richaud, T Bouchez, L Mazeas, F Farcas, et al.. The Role of Oxidation Compounds in Biofilm Growth on Polyethylene Geomembrane Barriers Used in Landfill. Journal of Applied Polymer Science, 2012, 124, pp.E251-257. 10.1002/app.36463 . hal-01202976

\section{HAL Id: hal-01202976 \\ https://hal.science/hal-01202976}

Submitted on 22 Sep 2015

HAL is a multi-disciplinary open access archive for the deposit and dissemination of scientific research documents, whether they are published or not. The documents may come from teaching and research institutions in France or abroad, or from public or private research centers.
L'archive ouverte pluridisciplinaire HAL, est destinée au dépôt et à la diffusion de documents scientifiques de niveau recherche, publiés ou non, émanant des établissements d'enseignement et de recherche français ou étrangers, des laboratoires publics ou privés. 


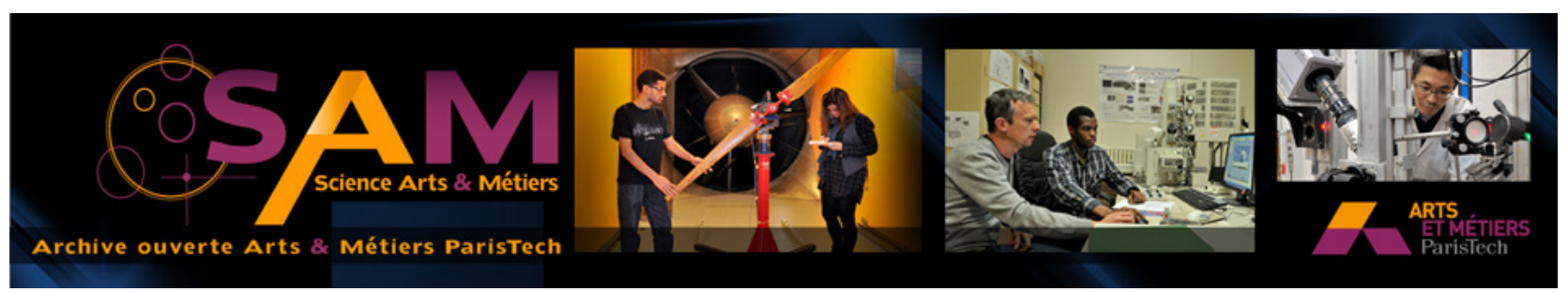

\section{Science Arts \& Métiers (SAM)}

is an open access repository that collects the work of Arts et Métiers ParisTech researchers and makes it freely available over the web where possible.

This is an author-deposited version published in: http://sam.ensam.eu

Handle ID: .http://hdl.handle.net/10985/10094

\section{To cite this version :}

C PONS, Emmanuel RICHAUD, T BOUCHEZ, L MAZEAS, F FARCAS, B FAYOLLE - The Role of Oxidation Compounds in Biofilm Growth on Polyethylene Geomembrane Barriers Used in Landfill - Journal of Applied Polymer Science - Vol. 124, p.E251-257. - 2012 


\title{
The Role of Oxidation Compounds in Biofilm Growth on Polyethylene Geomembrane Barriers Used in Landfill
}

\author{
C. Pons, ${ }^{1}$ E. Richaud, ${ }^{2}$ T. Bouchez, ${ }^{3}$ L. Mazeas, ${ }^{3}$ F. Farcas, ${ }^{1}$ B. Fayolle ${ }^{2}$ \\ ${ }^{1}$ IFSTTAR, Département Matériaux, Groupe Comportement Physico-chimique et Durabilité des Matériaux, \\ 75732 Paris Cedex 15, France \\ ${ }^{2}$ Arts et Métiers ParisTech, CNRS, PIMM UMR 8006, 75013 Paris, France \\ ${ }^{3}$ Cemagref, Unité de recherche Hydrosystèmes et bioprocédés, 92761 Antony Cedex, France
}

\begin{abstract}
In a model study, polyethylene was preoxidized and incubated for a period of 7 months at $40^{\circ} \mathrm{C}$ in two different municipal solid waste leachates. During the postexperimental analyses, specific attention was paid to the carbonyl species and carboxylic acid depletion during the environmental exposure because it is well known that carboxylic acids are believed to be a potential substrate for the development of microorganisms. The results showed that the carbonyl as well
\end{abstract}

as the carboxylic acid depletion observed follows first-order kinetics. The biofilm formation was characterized using a suite of analytical techniques, and its formation was compared with the carboxylic acid and carbonyl depletion profile. (C) 2012 Wiley Periodicals, Inc. J Appl Polym Sci 124: E251-E257, 2012

Key words: biofilm; oxidation; polyethylene; carboxylic acid; extraction kinetics

\section{INTRODUCTION}

Despite the best efforts for the development of recycling and reuse of polymers, today in most countries, storage is still the elimination mode of necessity for nonhazardous waste. To reduce the associated environmental risks, new regulations require the establishment of geomembrane barriers that are used as basal- and side-slope liners in the landfills. These systems are specifically manufactured from a geomembrane that is usually polyethylene (PE) because of its great chemical and biological inertia. However, the possible presence of oxygen in landfill can generate PE geomembrane degradation by oxidation process leading to risks of environmental pollution.

PE geomembranes are not subjected to photooxidation phenomena as they are located at the base of the landfill. However, they undergo a thermal oxidation at temperatures ranging between 30 and $60^{\circ} \mathrm{C}_{1}^{1-4}$ which are generated by various exothermal waste degradation reactions. At the same time, PE geomembranes are continuously in contact with a rich and diverse population of microorganisms. Numerous studies have shown that once oxidized, the hydrophilic nature of polar groups of the PE, as carbonyl compounds, allows biofilm formation ${ }^{5}$ and that it can be degraded by microorganisms. ${ }^{6-13} \mathrm{~A}$

Correspondence to: F. Farcas (fabienne.farcas@ifsttar.fr). thermal and biological synergistic effect may exist between the oxidation and the biodegradation processes. ${ }^{14}$

The kinetics for the thermal oxidation of polymers involves a radical process governed by the temperature $^{15}$ and oxygen. ${ }^{16}$ Hydroperoxides $(\mathrm{POOH})$ can be considered as the key products of the oxidation for the following reasons:

- Hydroperoxides are both initiation and propagation products. This means that the oxidation generates its own initiator. ${ }^{17}$

- The possible role of impurities that initiate oxidation can be represented by an equivalent concentration of hydroperoxides that are present initially. ${ }^{18}$

- Hydroperoxide decomposition leads to the formation of most of the carbonyl compounds (e.g., carboxylic acids, ketones, and esters). ${ }^{19}$ This is accompanied by a chain scission process, which leads to a decrease in molar mass. It has been proposed that small-sized carbonyl compounds (with low molecular weights) are bioavailable. $^{14}$

To date, most of the studies on PE biodegradation have been conducted in media containing pure bacterial strains ${ }^{7,8,10}$ or composts. ${ }^{11,13,20}$ So far, to the best of our knowledge, none have been conducted in a more environmentally representative ecosystem such as the complex media Municipal Solid Waste (MSW) leachate used in this study. 
To enhance the long-term performance of the PE geomembranes, it is necessary to gain a greater understanding of the mechanisms of aging of PE in MSW landfills. Thus, this study aimed at determining the nature and the kinetics of the extracted carbonyl species. The PE was first preoxidized and incubated for 7 months at $40^{\circ} \mathrm{C}$ in MSW leachate. Finally, the identity of the oxidation products is compared with the biofilm growth on the polymer surface.

\section{EXPERIMENTAL}

\section{Materials}

The PE used in this study was a medium density grade supplied as an additive-free powder. Its average number mass, $M_{n}=13 \mathrm{~kg} \mathrm{~mol}^{-1}$, and weight molar mass, $M_{w}=214 \mathrm{~kg} \mathrm{~mol}^{-1}$ (polydispersity index $=16.2$, were determined using high-temperature gel permeation chromatography (GPC) analysis.

Films were obtained by compression molding the powder at $170^{\circ} \mathrm{C}$ for $50 \mathrm{~s}$ under $20 \mathrm{MPa}$ (after $50 \mathrm{~s}$ of heating time) using a Gibritte laboratory press. The films of about $300 \mu \mathrm{m}$ were obtained to avoid any diffusion effects.

Prior to exposure and contact with the leachate, films were preoxidized at $105^{\circ} \mathrm{C}$ in ventilated ovens. The duration of the exposure was adjusted to obtain a $0.056 \mathrm{~mol} \mathrm{~kg}^{-1}$ overall carbonyl concentration [as determined by Fourier transform infrared (FTIR) spectroscopy, see later]. Some control comparison experiments were carried out with PE films not subject to oxidation before leachate ageing.

Leachate was collected in a landfill in which appropriate waste were stored for 10 years. Its $\mathrm{pH}$ was measured and found to be about 8 . PE samples were exposed to contact with this raw leachate as well as to the presence of an abiotic leachate obtained by adding $0.01 \mathrm{wt} \%$ of Thiomersal to the raw leachate to create one which can inhibit microorganism growth. ${ }^{12}$

\section{Characterization}

FTIR spectra were obtained using a Nicolet Impact 400 apparatus driven by Omnic 5.1 software (supplied by Thermoelctron, 91963 Courtaboeuf, France). Spectra for free-standing films in absorbance mode were obtained by averaging 32 scans at a resolution of $4 \mathrm{~cm}^{-1}$.

The carbonyl concentration was calculated from the following absorbance values using the BeerLambert law:

- $300 \mathrm{~L} \mathrm{~mol}^{-1} \mathrm{~cm}^{-1}$ as molar absorptivity for overall carbonyl species. ${ }^{21}$ This was used to plot kinetic curves for carbonyl build-up.
- $680 \mathrm{~L} \mathrm{~mol}^{-1} \mathrm{~cm}^{-1}$ for carboxylic acids. ${ }^{21}$ These are expected to be the main nutriment for microorganism growth. ${ }^{22}$

\section{Attenuated total reflexion (ATR)}

Microorganism growth resulted in the formation of a biofilm at the surface of the PE samples, ${ }^{10,12}$ which was characterized by FTIR in attenuated total reflexion (ATR) mode using a Diamond crystal (Durascope provided by AccessIr, 54290 Bremoncourt, France). Using this technique, the depth of analysis of the evanescent wave is about 1.0-2.0 $\mu \mathrm{m}$.

\section{Ammonia treatment}

Oxidized films were treated with gaseous ammonia to determine the nature of the oxidation products as $\mathrm{NH}_{3}$ converts carboxylic acids into carboxylates and esters into amides. ${ }^{23,24}$ Gaseous ammonia was generated from an equimolar solution of $\mathrm{NH}_{4} \mathrm{Cl}(12 \mathrm{~g})$ and $\mathrm{NaOH}(10 \mathrm{~g})$ in $100 \mathrm{~mL}$ of water. Films were exposed to ammonia in a closed vessel for about $72 \mathrm{~h}$ at room temperature before FTIR measurements were carried out.

\section{Scanning electron microscopy/microanalysis X}

Microorganism growth at the polymer surface was observed using scanning electron microscopy (SEM). A Quanta 400 apparatus (provided by FEI, 5651 GG Eindhoven, The Netherlands FEI) with various magnifications was used. Electrons were accelerated using a 15 or $30 \mathrm{keV}$ electric field. Gold-coated samples were obtained using a Bal-Tec SCD004 (provided by Bal Tech, Inc., St. Paul Park, Minnesota, US) Sputter Coater. X-ray microanalysis was performed by SEM/EDAX DX 4i (provided by FEI, 5651 GG Eindhoven, The Netherlands). The scanning energy for EDAX analysis was from 15 to $30 \mathrm{keV}$ with an elapsed time of $100 \mathrm{~s}$.

\section{Exposure conditions}

Preoxidation was performed at $105^{\circ} \mathrm{C}$ in ventilated ovens (WTB Binder). Exposure experiments in contact with either the biotic or abiotic leachate were performed by immersing the PE films in $30 \mathrm{~mL}$ hermetic flasks containing $10 \mathrm{~mL}$ of landfill leachate. Samples were put in ovens at $40^{\circ} \mathrm{C}$ to study the growth of the biofilm. Abiotic controls were obtained by adding 0.01 wt $\%$ of Thiomersal. The temperature was chosen as close as possible to the value at the base of the landfill to select the same type of microorganisms. Sample size was adjusted to ensure a total immersion.

Exposures were carried out for up to 50 days during which infrared analyses were performed at different time periods. It should be mentioned that 


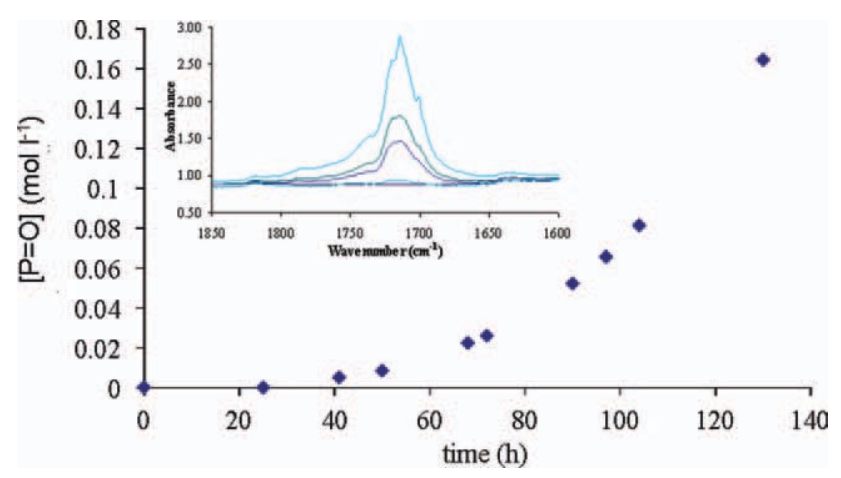

Figure 1 Kinetic curve for carbonyl formation at $105^{\circ} \mathrm{C}$ and corresponding changes in FTIR spectra. [Color figure can be viewed in the online issue, which is available at wileyonlinelibrary.com.]

samples were not reintroduced in the leachate after analysis.

\section{RESULTS AND DISCUSSION}

\section{Preoxidation prior to leachate exposure}

The accelerated oxidation of PE was carried out in a ventilated oven at $105^{\circ} \mathrm{C}$ under atmospheric pressure. The level of oxidation was determined from the increase in the carbonyl absorbance as measured using infrared spectrophotometry (FTIR). The BeerLambert law [eq. (1)] was applied to the maximum peak located at $1715 \mathrm{~cm}^{-1}$ to determine the concentration from the optical density as follows:

$$
[\mathrm{CO}]=\frac{\mathrm{DO}_{1715}}{\varepsilon_{1715} \times d \times l}
$$

where [CO] is the concentration of the carbonyl group $\left(\mathrm{mol} \mathrm{kg}^{-1}\right), l$ is the sample thickness (in centimeters), and $d$ is the density equal to $0.935 \mathrm{~kg} \mathrm{~L}^{-1}$. $\varepsilon_{1715}$ is the molar absorptivity taken equal to $300 \mathrm{~L}$ $\mathrm{mol}^{-1} \mathrm{~cm}^{-1}$ for overall carbonyl species. ${ }^{21} \mathrm{IR}$ spectrum changes in the carbonyl region and kinetics curves for carbonyl build-up at $105^{\circ} \mathrm{C}$ are shown in Figure 1. A concentration of carbonyls $[\mathrm{CO}]=0.056 \mathrm{~mol} \mathrm{~kg}{ }^{-1}$ was chosen at a specific time after the induction period (Fig. 1). To characterize the polymer on a macromolecular scale, GPC measurements were performed. After the preoxidation treatment, it was found that the molar mass values were significantly lower than the initial molar mass values: $M_{w}=21250 \mathrm{~g} \mathrm{~mol}^{-1}$ and $M_{n}=5050 \mathrm{~g}$ $\mathrm{mol}^{-1}$ leading to a polydispersity value of 4.25 .

According to Albertsson et al., ${ }^{6}$ carboxylic acids correspond to the degradation products formed on the oxidation of PE. To know the mechanisms involved in the aging of PE in landfills, quantification of the extracted carboxylic acids is required. After derivatization using an ammonia gas treatment, infrared spectrophotometry was used to analyze the samples.

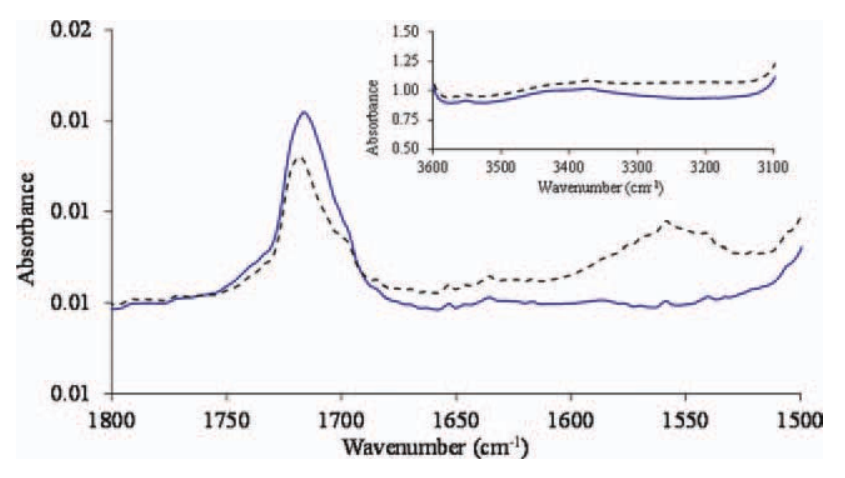

Figure 2 Changes in PE FTIR spectra in the carbonyl region (1500-1800 $\mathrm{cm}^{-1}$ ) and in the hydroxyl region (3100-3600 $\mathrm{cm}^{-1}$ ) for samples exposed for $120 \mathrm{~h}$ at $105^{\circ} \mathrm{C}$, both before and after $\mathrm{NH}_{3}$ treatment. [Color figure can be viewed in the online issue, which is available at wileyonlinelibrary.com.]

The preoxidized samples were incubated in the biotic leachate for a specific time period. They were then exposed to the $\mathrm{NH}_{3}$ gas at room temperature for $72 \mathrm{~h}$.

The reaction of carboxylic acids $(\mathrm{RCOOH})$ with ammonia $\left(\mathrm{NH}_{3}\right)$ is given by the following equation:

$$
\mathrm{RCOOH}+\mathrm{NH}_{3} \rightarrow \mathrm{RCOO}^{-}+\mathrm{NH}_{4}^{+}
$$

The carboxylates generated $\left(\mathrm{RCOO}^{-}\right)$are easily identifiable by their infrared absorption in 1560 $\mathrm{cm}^{-1}$ band range; the appearance of this band is accompanied by a decrease in the 1800 and 1650 $\mathrm{cm}^{-1}$ region, which is characteristic of carbonyl compounds. The presence of carboxylic acids can then be measured by subtracting the spectra from before and after derivatization. The effect of the $\mathrm{NH}_{3}$ treatment is illustrated in Figures 2 and 3. Reaction between $\mathrm{NH}_{3}$ and the carbonyl compounds generated by the oxidation leads to the following changes in FTIR spectra:

- A decrease in the $1715 \mathrm{~cm}^{-1}$ band accompanied by an increase in that of $1550 \mathrm{~cm}^{-1}$ due to conversion of carboxylic acids into carboxylate.

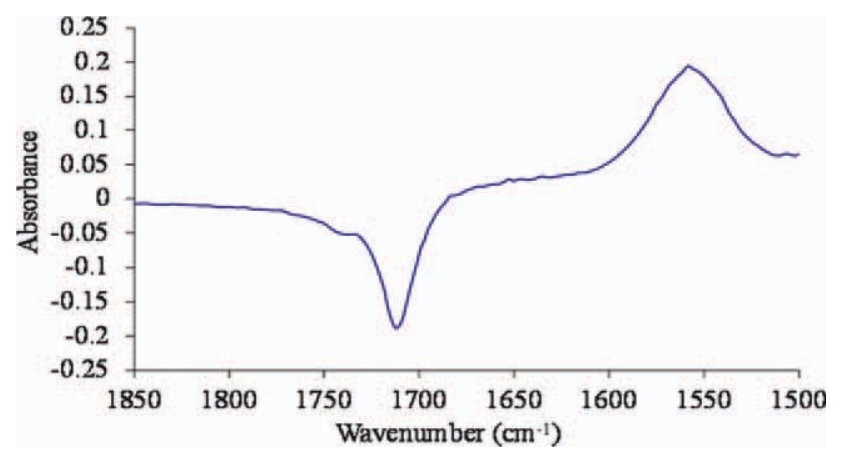

Figure 3 Subtraction of FTIR spectra, after $\mathrm{NH}_{3}$ treatment and reference PE before treatment, for samples exposed for $120 \mathrm{~h}$ at $105^{\circ} \mathrm{C}$. [Color figure can be viewed in the online issue, which is available at wileyonlinelibrary.com.] 


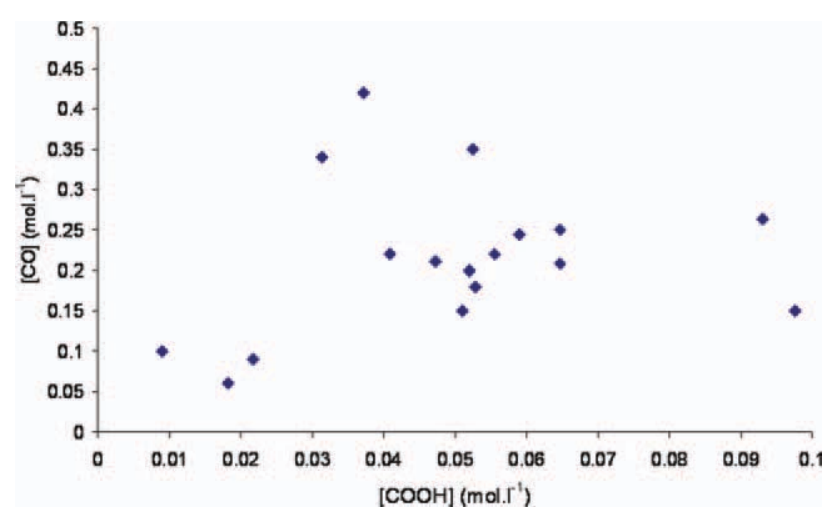

Figure 4 Carbonyl concentration $(\mathrm{CO})$ as a function of carboxylic acid $(\mathrm{COOH})$ concentration during preoxidation. [Color figure can be viewed in the online issue, which is available at wileyonlinelibrary.com.]

- A shoulder in the subtraction peak at $1735 \mathrm{~cm}^{-1}$ accompanied by an increase at $3200 \mathrm{~cm}^{-1}$ due to the conversion of esters into amides.

The carbonyl concentrations were calculated from the classical Beer-Lambert law using the following extinction coefficients: $\varepsilon$ (global carbonyl) $=$ $300 \mathrm{~L} \mathrm{~mol}^{-1} \mathrm{~cm}^{-1}$ (Ref. 21); $\varepsilon$ (carboxylic acids) $=$ $680 \mathrm{~L} \mathrm{~mol}^{-1} \mathrm{~cm}^{-1}$ (Ref. 21); $\varepsilon$ (esters) $=350 \mathrm{~L} \mathrm{~mol}^{-1}$ $\mathrm{cm}^{-1}$ (Ref. 25); and $\varepsilon$ (ketones) $=300 \mathrm{~L} \mathrm{~mol}^{-1} \mathrm{~cm}^{-1}$ (Ref. 21).

As a result, the following concentrations for carbonyl species were calculated:

- For global carbonyl build-up: [CO] $\sim 0.056 \mathrm{~mol} \mathrm{~L}^{-1}$ from a maximal absorbance at $1715 \mathrm{~cm}^{-1}$.

- For carboxylic acids: $[\mathrm{COOH}] \sim 0.010 \mathrm{~mol} \mathrm{~L}^{-1}$ from the difference between $\mathrm{NH}_{3}$-untreated and -treated samples.

- For esters: $[\mathrm{E}] \sim 0.001 \mathrm{~mol} \mathrm{~L}^{-1}$ from the difference between $\mathrm{NH}_{3}$-untreated and -treated samples.

- For ketones: $[\mathrm{K}] \sim 0.044 \mathrm{~mol} \mathrm{~L}^{-1}$ from the residual absorbance after $\mathrm{NH}_{3}$ treatment or from the subtraction of carboxylic acid and ester concentrations from the global carbonyl concentration.

As a result, about $20 \%$ of the global carbonyl species generated during preoxidation process are carboxylic acids. According to Figure 4, this percentage has been confirmed for all samples during the preoxidation process.

\section{Extraction coefficients of carbonyl compounds}

Incubation of the preoxidized PE films incubated in biotic and abiotic leachates under aerobic conditions lead to a decrease in the band, which is characteristic of the carbonyl band located between 1800 and
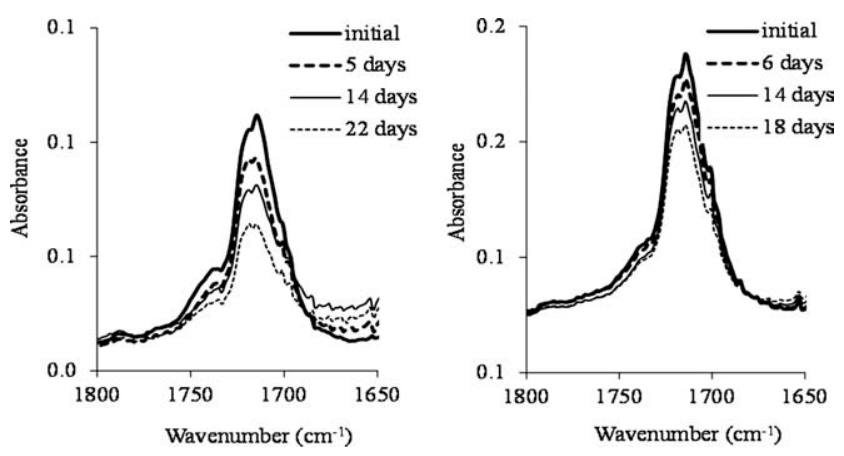

Figure 5 IR spectra changes of preoxidized PE films during exposure to biotic (a) and abiotic MSW leachates under aerobic conditions (b).

$1650 \mathrm{~cm}^{-1}$ (Fig. 5). By knowing that the carbonyl decrease is observed irrespective of the medium (biotic or abiotic), one can safely conclude that the main mechanism capable of explaining this drop is a physical extraction of the chains containing the carbonyl compounds. Indeed, the chains containing polar groups and having a low molar mass are suitable for promoting an extraction process by the medium. Furthermore, these results are in good agreement with those obtained by Koutny et al. ${ }^{12}$ Their study highlights the extraction of carbonyl compounds from PE samples in aqueous medium using nuclear magnetic resonance spectroscopy. However, these authors did not quantify concentrations of the extracted compounds and rates of extraction.

The observed carbonyl drop can be explained only by a physical extraction of carbonyl compounds from the PE to the medium. This physical extraction can also involve a diffusion process in the case of thick samples. By assuming that extraction kinetics are not controlled by diffusion (thin samples in our case), carbonyl concentration in logarithm scale was plotted as a function of exposure time. According to the results shown in Figure 6, the concentration of carbonyl on the log scale is proportional to the

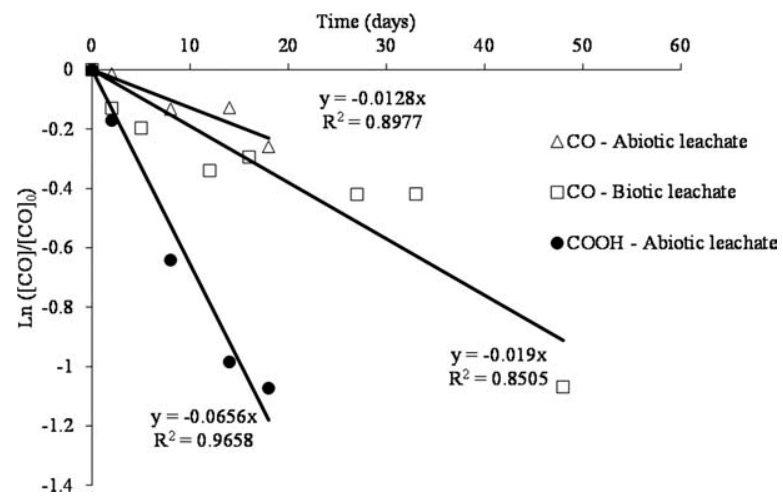

Figure $6 \mathrm{CO}$ or $\mathrm{COOH}$ kinetics for PE preoxidized samples incubated in either biotic or abiotic leachate extraction under aerobic conditions. 

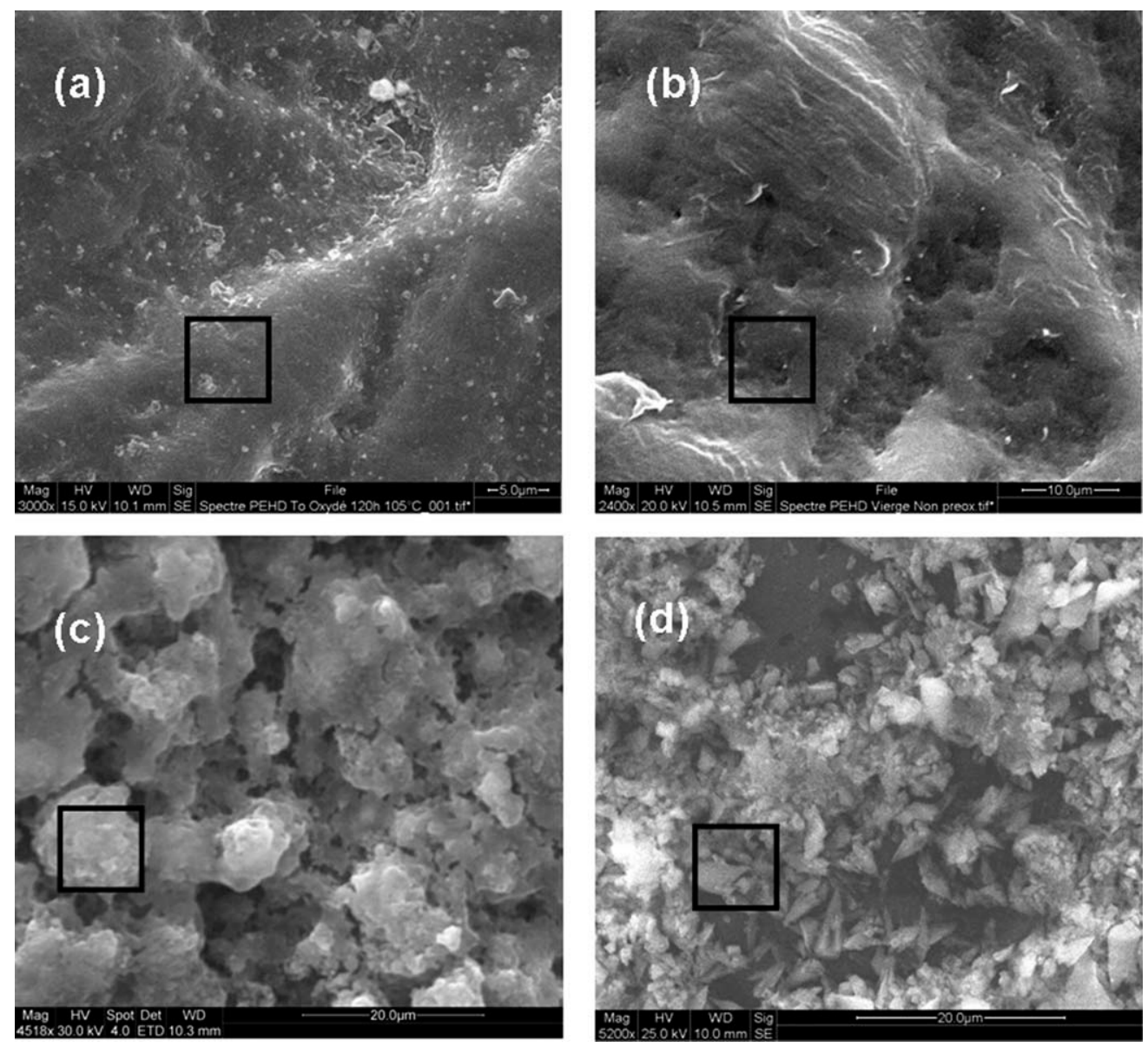

Figure 7 SEM images of the surface of films of PE (a) preoxidized before incubation; (b) unoxidized before incubation; (c) preoxidized and incubated for 7 months in aerobic leachate; and (d) unoxidized and incubated 7 months in aerobic leachate.

exposure time for the PE samples incubated in MSW with either landfill leachate or abiotic leachate. In accordance with other published results for stabilizer physical loss, ${ }^{26-28}$ our results clearly indicate that the loss of the carbonyl follows first-order kinetics.

To model and quantify the extraction process, the following relationship can be used $^{26}$ :

$$
\frac{d[\mathrm{CO}]}{d \mathrm{t}}=-H_{\mathrm{CO}}[\mathrm{CO}]
$$

where $\mathrm{CO}$ is the concentration of the residual carbonyl $\left(\mathrm{mol} \mathrm{L}^{-1}\right)$ species and $H_{\mathrm{CO}}$ is the coefficient of extraction $\left(\right.$ day $\left.^{-1}\right)$ for the overall carbonyl species.

The coefficients of extraction were calculated as $H_{\mathrm{CO}} \sim 1.3 \times 10^{-2}$ day $^{-1}$ and $H_{\mathrm{CO}} \sim 1.9 \times 10^{-2}$ day $^{-1}$ for the abiotic and biotic leachates, respectively. These results clearly show that the coefficients of extraction are similar irrespective of the medium used.

During the extraction procedure, the residual amount of carboxylic acids was also quantified using the $\mathrm{NH}_{3}$ treatment (Fig. 6). The extraction coefficient was calculated as $6.6 \times 10^{-2} \mathrm{day}^{-1}$, that is, five times higher than found for the corresponding global carboxylic acids.

This ratio can be justified as follows: by expressing the extraction rate for $\mathrm{COOH}$ (carboxylic acids) and for overall carbonyl CO on the assumption that carboxylic acids are in fact the only carbonyls extracted, that is,

$$
d[\mathrm{CO}] / d t=d[\mathrm{COOH}] / d t
$$

Then:

$$
\frac{H_{\mathrm{COOH}}}{H_{\mathrm{CO}}}=\frac{[\mathrm{CO}]}{[\mathrm{COOH}]}
$$

From the results presented in Figure 6, the ratio of $H_{\mathrm{COOH}} / H_{\mathrm{CO}}$ can be estimated as being close to 5 . It should be noted that this value is similar to the concentration ratio for the $\mathrm{CO}$ and $\mathrm{COOH}$ values, which was assessed as being close to 4 (Fig. 4).

\section{Biofilm formation}

Both preoxidized and unoxidized PE film surfaces were analyzed using electronic microscopy in 
TABLE I

X-ray Microanalysis

\begin{tabular}{|c|c|c|c|c|}
\hline $\begin{array}{l}\text { Sample } \\
\text { elements } \\
\text { (\% mass) }\end{array}$ & $\begin{array}{c}\text { Sample (a): } \\
\text { oxidized } \\
\text { PE surface }\end{array}$ & $\begin{array}{l}\text { Sample (b): } \\
\text { unoxidized } \\
\text { PE surface }\end{array}$ & $\begin{array}{l}\text { Sample (c): Biofilm } \\
\text { on the surface of PE } \\
\text { preoxidized and } \\
\text { incubated in } \\
\text { MSW leachate }\end{array}$ & $\begin{array}{l}\text { Sample (d): Crystals } \\
\text { on the surface of } \\
\text { unoxidized PE and } \\
\text { incubated in } \\
\text { MSW leachate }\end{array}$ \\
\hline C & 87.15 & 88.71 & 21.65 & 32.76 \\
\hline $\mathrm{O}$ & - & - & 37.47 & 42.54 \\
\hline $\mathrm{Na}$ & - & - & 2.58 & - \\
\hline $\mathrm{Mg}$ & - & - & 8.90 & 0.68 \\
\hline $\mathrm{Si}$ & - & - & 14.77 & 0.61 \\
\hline $\mathrm{Au}$ & 12.85 & 11.29 & 10.11 & 6.70 \\
\hline $\mathrm{Cl}$ & - & - & 0.80 & - \\
\hline K & - & - & 1.61 & - \\
\hline $\mathrm{Ca}$ & - & - & 2.11 & 16.71 \\
\hline
\end{tabular}

scanning mode (SEM). The SEM photographs of the unoxidized [Fig. 7(b)] and preoxidized [Fig. 7(a)] PE samples before incubation show a smooth surface. In contrast, the SEM photographs of the preoxidized PE films, which were incubated in the leachate for 7 months [Fig. 7(c)], highlight the presence of large heterogeneous aggregates. These can most certainly correspond to clusters of microorganisms that have colonized the surface of the polymer as a biofilm. There are literature reports of similar results having been obtained after the incubation of HDPE (High Density Polyethylene) and LDPE (Low Density Polyethylene) films with nonspecific leachate pure strains or natural complex media such as composts or soil. ${ }^{20}$ It should be noted, however, that the formation of a biofilm does not necessarily imply the biodegradation of the material. ${ }^{29}$ However, the presence of the biofilm at the polymer surface can be a potential danger for biodegradation.

In Figure $7(\mathrm{~d})$, the presence of many crystals on the surface of the unoxidized PE after incubation for 7 months in the leachate can be clearly observed. From the X-ray microanalysis shown in Table I, it appears that these crystals consist mostly of carbon, oxygen, and calcium. Therefore, these results suggest that precipitates of calcium carbonates $\left(\mathrm{CaCO}_{3}\right)$ from the leachate are deposited on the surface of the preoxidized PE on incubation. Indeed, it is well known that during anaerobic metabolism of microorganisms, carbon dioxide is produced. Depending on the $\mathrm{pH}$ of the leachate, a balance between the amount of carbon dioxide and carbonates is established. ${ }^{30}$

The results of $\mathrm{X}$-ray microanalysis of this surface biofilm of the preoxidized PE show that it consists of both organic and mineral components. These results are consistent with those presented in the literature. ${ }^{31}$ In fact, it is a highlighted feature for all the biofilms studied.

The existence of a biofilm on the surface of the preoxidized PE was confirmed using FTIR spectro- photometry in ATR mode (Fig. 8). The analysis of the film surface, aged 48 days, highlights the presence of absorption bands between $3600-3000 \mathrm{~cm}^{-1}$ and $1653 \mathrm{~cm}^{-1}$ that correspond to protein material. Bands in the $1200-900 \mathrm{~cm}^{-1}$ region are due to the polysaccharide cellular constituents of microorganisms. The change in the spectra as shown in Figure 8 after various sample contact times highlights an increase in the characteristic microorganism bands as a result of a thickening of the biofilm.

In the case of the unoxidized PE films incubated under aerobic conditions, no changes in the FTIR spectra were observed. In other words, the spectra do not reveal any of the characteristic protein bands between $3000-3600 \mathrm{~cm}^{-1}$ and $1653 \mathrm{~cm}^{-1}$.

There are two possible hypotheses that could explain the observed results:

(i). The bacterial growth on the surface of the preoxidized PE is accelerated by the presence of acid carboxylic compounds resulting from oxidation.

(ii). Because of the hydrophobic nature of the surface of nonoxidized PE and the concomitant

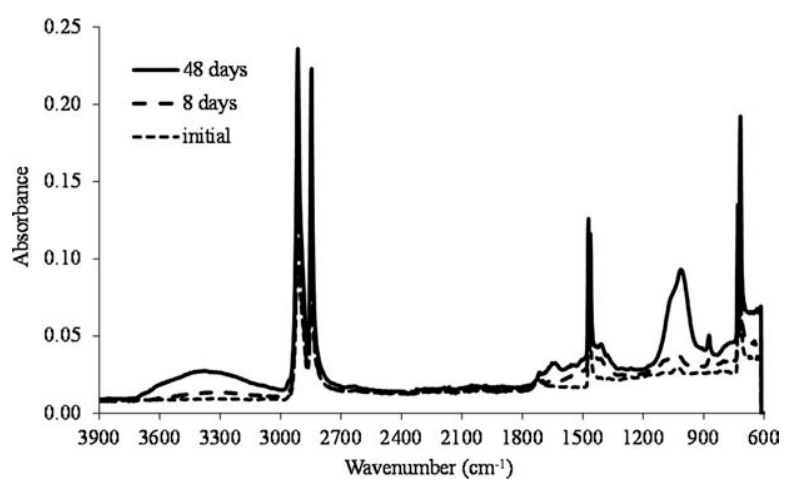

Figure 8 FTIR-ATR spectral changes during incubation in biotic MSW leachate under aerobic conditions. 
hydrophilic nature of the surface of the microorganisms found in the leachate, it is not unexpected that there is little attraction between the two.

\section{CONCLUSION}

To provide evidence for possible interactions between PE geomembranes and MSW leachates, the biochemical modification of well-characterized preoxidized PE films was followed during exposure to both biotic and abiotic leachates at $40^{\circ} \mathrm{C}$. As oxidation products can constitute a favorable substrate for microorganism formation, concentration measurements of such oxidation products, in particular carboxylic acids, were performed. A linear relationship between the overall carbonyl species and the carboxylic acid content was established. One clear outcome of the incubation experiments is that both carbonyl species and carboxylic acids are extracted by the leachate, and the kinetic loss follows first-order kinetics irrespective of the nature of the leachate. Concomitantly, the biofilm formation was followed using FTIR in ATR mode as well as SEM. The results indicate that biofilm formation appears to be intimately related to the oxidation products found at the sample surface.

This study is part of the DURAGEOS project, in the frame of the C2D2 program in the RGC\&U Network of MEDDTL (French Ministry in charge of Ecology and Transport). The DURAGEOS project is labeled by the competitivity poles ADVANCITY and AXELERA. The project partners are as follows: IFSTTAR, Cemagref, LTHE of the Joseph Fourier University, ENTPE, PIMM Laboratory of Arts et Métiers Paris Tech, Suez Environnement, and Véolia Propreté.

\section{References}

1. Rowe, R. K. Geotechnique 2005, 5, 631.

2. Koerner, G. R.; Koerner, R. M. Geotex Geomembr 2006, 24, 72.

3. Yoshida, H.; Rowe, R. K. In Proceedings of the Ninth International Waste Management and Landfill Symposium, CISA, Italy (CD-ROM); Christensen, T. H., et al., Eds.; 2003.

4. Koerner, R. M.; Koerner, G. R.; Eith, A. W.; Ballod, C. P. In Global Waste Management Symposium, National Solid Wastes
Management Association, Copper Mountain, Colorado, USA (CD-ROM); 2008.

5. Hadad, D.; Geresh, S.; Sivan, A. J Appl Microbiol 2005, 98, 1093.

6. Albertsson, A. C.; Barenstedt, C.; Karlsson, S.; Lindberg, T. Polymer 1995, 36, 3075.

7. Albertsson, A. C.; Erlandsson, B.; Hakkarainen, M.; Karlsson, S. J Environ Polym Degrad 1998, 6, 187.

8. Weiland, M.; Daro, A.; David, C. Polym Degrad Stab 1995, 48, 275.

9. Yamada-Onodera, K.; Mukumoto, H.; Katsuyaya, Y.; Saiganji, A.; Tani, Y. Polym Degrad Stab 2001, 72, 323.

10. Bonhomme, S.; Cuer, A.; Delort, A. M.; Lemaire, J.; Sancelme, M.; Scott, G. Polym Degrad Stab 2003, 81, 441.

11. Jakubowicz, I. Polym Degrad Stab 2003, 80, 39.

12. Koutny, M.; Sancelme, M.; Dabin, C.; Pichon, C.; Delort, A. M.; Lemaire, J. J. Polym Degrad Stab 2006, 91, 1495.

13. Chiellini, E.; Corti, A.; D'Antone, S. Polym Degrad Stab 2007, 92, 1378.

14. Albertsson, A. C.; Andersson, S. O.; Karlsson, S. Polym Degrad Stab 1987, 18, 73.

15. Colin, X.; Fayolle, B.; Audouin, L.; Verdu, J. Polym Degrad Stab 2003, 80, 67.

16. Richaud, E.; Farcas, F.; Bartoloméo, P.; Fayolle, B.; Audouin, L.; Verdu, J. Polym Degrad Stab 2006, 91, 398.

17. Audouin, L.; Gueguen, V.; Tcharkhtchi, A.; Verdu, J. J Polym Sci Part A: Polym Chem 1995, 33, 921.

18. Richaud, E.; Colin, X.; Fayolle, B.; Audouin, L.; Verdu, J. Int J Chem Kinet 2008, 40, 769.

19. Gugumus, F. Polym Degrad Stab 2002, 76, 381.

20. Ojeda, T. F. M.; Dalmolin, E.; Forte, M. M. C.; Jacques, R. J. S.; Bento, F. M.; Camargo, F. A. O. Polym Degrad Stab 2009, 94, 965.

21. Rugg, F. M.; Smith, J. J.; Bacon, R. C. J Polym Sci Part A: Polym Chem 1954, 13, 535.

22. Maquelin, K.; Kirschner, C.; Choo-Smith, L.-P.; Van den Braak, N.; Endtz, H. P.; Naumann, D.; Puppels, G. J. J Microbiol Methods 2002, 51, 2002.

23. Rivaton, A.; Lalande, D.; Gardette, J. L. Nucl Instrum Methods 2004, 222, 187.

24. Rivaton, D.; Gardette, J. L. Polym Degrad Stab 1999, 66, 385.

25. Lacoste, J.; Vaillant, D.; Carlsson, J. J Polym Sci Part A: Polym Chem 1993, 31, 715.

26. Calvert, P. D.; Billingham, N. C. J Appl Polym Sci 1979, 24, 357.

27. Djouani, F.; Richaud, E.; Fayolle, B.; Verdu, J. Polym Degrad Stab 2011, 96, 1349.

28. Colin, X.; Verdu, J.; Rabaud, B. Polym Eng Sci 2001, 51, 1541.

29. Eubeler, J. P.; Bernhard, M.; Knepper, T. P. Anal Chem 2009, 28, 1057.

30. Kjeldsen, P.; Barlaz, M. A.; Rooker, A. P. Crit Rev Environ Sci Technol 2002, 32, 297.

31. Fritz-Feugeas, F.; Cornet, A.; Tribollet, B., Eds. Ellipses, France; 2008, 101-121. 